\title{
The Roles of Foundations and Universities in Redevelopment Planning
}

\author{
Laurie A. Walker and Jean F. East
}

\begin{abstract}
Laurie A. Walker, the 2017 recipient of the Ernest A. Lynton Award for the Scholarship of Engagement, is an Associate Professor in the School of Social Work at the University of Montana. Together with her co-author, Dr. Jean F. East, Professor in the Graduate School of Social Work at the University of Denver, they have raised, in this piece, an important and insightful critical lens on the implications of higher education institutions' "engagement" with their local communities. It looks deeply into the implications of the "blind spot" identified by Baldwin (2017), which "comes largely from the assumption that higher education, while hypnotized by corporate power, is still an inherent public good, most clearly marked by its taxexempt status for providing services that would otherwise come from the government.” They examine how campuses may be deeply involved in the local urban area and also advancing a self-interest that may not be a public interest - through gentrification, and through what Baldwin calls "noneducational investments in real estate, policing, and labor" that "can carry negative consequences for neighborhoods of color.” Walker and East are asking us to more closely examine how campuses can get so involved in the cities of which they are a part as to be a dominant force that does not advance the public good, but the good of the campus. This is a dilemma and a question that many of the CUMU member campuses have already faced or may face in the coming years, and goes to the heart of the public good of higher education in a neoliberal age.
\end{abstract}

— John Saltmarsh, University of Massachusetts, Boston

Keywords: Planning; public housing; resident engagement; qualitative

One goal for the Coalition of Urban and Metropolitan Universities (CUMU) 2017 conference in Denver, Colorado was to explore the role of urban universities as anchor institutions. Anchor institutions — such as universities, hospitals, parks, sports teams and stadiums — are often located within or adjacent to urban neighborhoods with a concentration of low-income residents, who could benefit from partnerships and investments designed to create more equitable and safe environments (Baldwin, 2017; Etienne, 2012; Rapson, 2008; Rutheiser, 2013). In recent years, anchor institutions have committed to a set of principles for working with communities that includes a high level of accountability. A consequence of the 1980s-1990s New Federalism was a deeper reliance on anchor institutions to solve problems not met by the private neoliberal market, e.g., crime in neighborhoods adjacent to universities (Etienne, 2012; Wilson, 1996). The new policy approach offered tax incentives for private investment (Enterprise Zones) while simultaneously decreasing federal investment in cities from an average of 18 percent to 6 percent (Wilson, 1996), resulting in drastic cuts to services in neighborhoods.

Metropolitan Universities Vol. 29 No. 2 (May 2018), DOI: 10.18060/22342 
The Kresge Foundation was the title sponsor of the CUMU 2017 conference in collaboration with the Annie E. Casey Foundation (Casey Foundation). Part of the Kresge Foundation's mission is to support universities globally in becoming anchor institutions (Rapson, 2008). The Casey Foundation, while not an anchor institution, has invested in supporting community organizing and development in low-income neighborhoods for almost 30 years and has invested in related anchor institution work for almost 15 years (Rutheiser, 2013).

\section{Denver Anchor Institution Case Studies}

This paper examines two case studies of anchor institution involvement in neighborhood development, then compares and contrasts them in order to understand the effectiveness of community engagement efforts (Pendergast, 2013). Given the locally driven solutions of neoliberal approaches, the roles of each collaborator in urban development-whether a university or a foundation-vary from city to city and project to project; however, the lessons learned via each case study are likely informative of work where universities and foundations explicitly identify as anchor institutions. Figure 1 depicts the neighborhood anchor institutions discussed in this article.

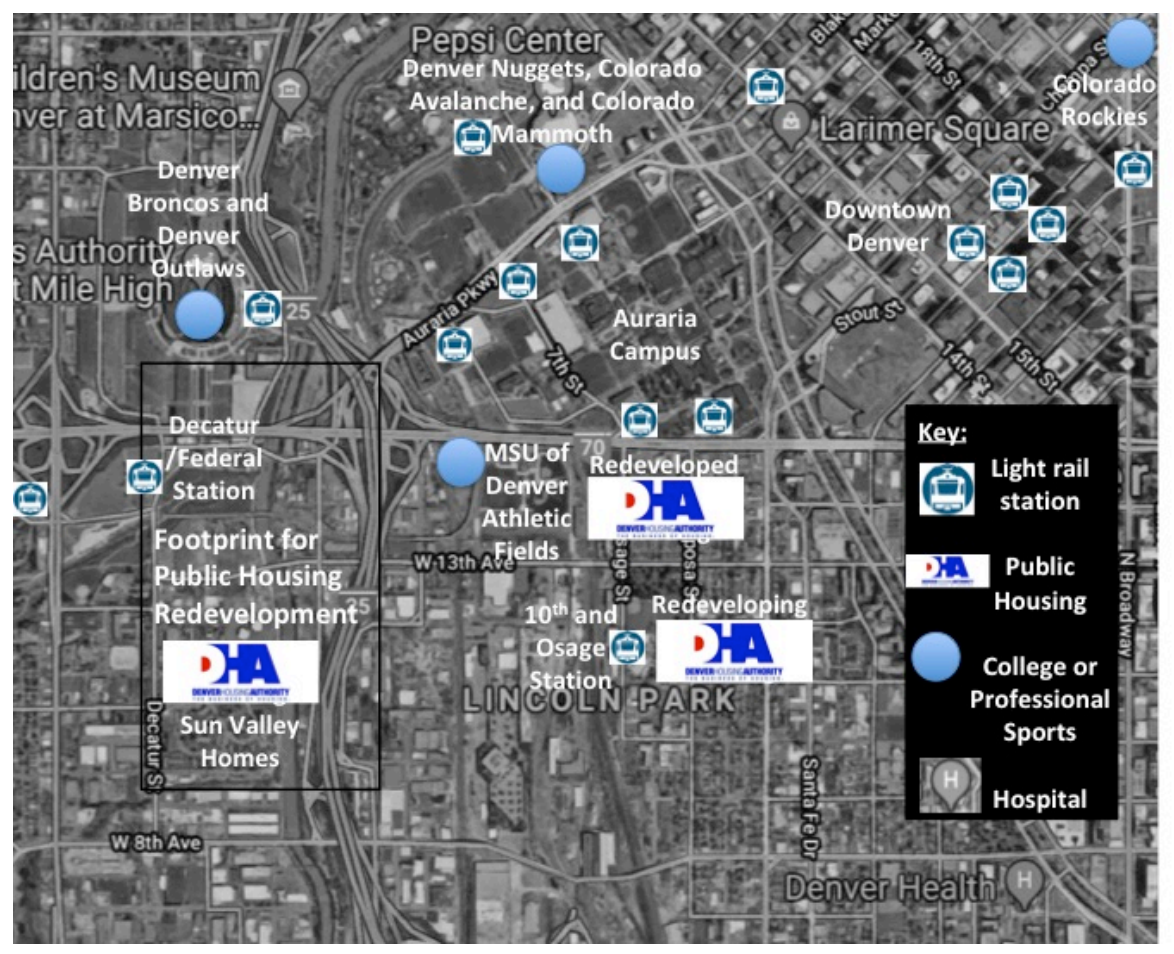

Figure 1. Sun Valley and La Alma/Lincoln Park Anchor Institutions.

The first case focuses on a public private partnership that grew out of a decade-long Casey Foundation Making Connections (MC-D) initiative to engage two neighborhoods adjacent to Auraria, Sun Valley and La Alma/Lincoln Park, as part of a ten-city nationwide effort to promote community change (Yates \& Saasta, 2013). In 2007, the Casey Foundation specifically invested in a Resident Advisory Council (RAC) process, in order to support a neighborhood and light rail 
planning that was more accessible to residents than the existing neighborhood and station area planning. The Casey Foundation accomplished the RAC process by collaborating with the community-based organizations (CBOs) where the foundation was already engaged. MC-D convened the community organizing and development staff they funded in planning a process that engaged residents and local anchor institutions (e.g., the housing authority and city government employees). This work indirectly engaged Denver universities via student internships and projects focused on neighborhood planning (United States Environmental Protection Agency, 2016; Walker \& East, 2014). The RAC process was evaluated utilizing federal funding received by the first author of this paper while a graduate student (Walker \& East, 2014).

The case empirically describes strategies used to facilitate system-wide changes during the planning phases of the neighborhoods' redevelopment. The case discussion emphasizes the potential and limitations of a foundation and contracted facilitator's roles in ensuring that publicprivate partnership dialogue leads to strategies promoting social justice, addressing historic and contemporary oppression, and take note of whether private sector interests dominate these collaborations (Fields, 2014). The findings focus on the role, structure, and capacity-building of one foundation and the neutral facilitator hired to help the partnership maintain affordable housing, address neighborhood problems like crime, and improve neighborhood human services and infrastructure.

The second case studies the 1976 development of a shared campus footprint, known as Auraria, via an urban renewal bond in 1969 to be home to three higher education institutions. Although the process was consistent with national use of Section 112 policy and outcomes, it displaced between 150 and 300 predominantly Latino/Latina families, who mostly moved south of Colfax Avenue into the La Alma/Lincoln Park (Brown, 2006; Etienne, 2012; Pendergast, 2013a).

Successful partnerships between Auraria and these neighborhoods requires being sensitive to the initial urban renewal and displacement concerns of residents (Etienne, 2012; Pendergast, 2013b). This case uses secondary data from the Auraria Campus media, an Environmental Impact Statement, and planning efforts related to the relocation the athletic fields into the La Alma/Lincoln Park neighborhood (AHEC, 2012 as cited in Pendergast, 2013b; Metropolitan State University of Denver, 2016; Pendergast, 2013a, 2013b, 2013c, and 2013d).

Metropolitan State University of Denver (MSU Denver) recently spent nearly \$200 million on campus development projects, which included building athletic facilities (Regency Athletic Complex) in the La Alma/Lincoln Park neighborhood (Metropolitan State University of Denver, 2016; Pendergast, 2013a). The Regency Athletic Complex development included community benefits related to removing environmental contaminates from the previous landowner. A Colorado university professor reported on: (a) the initial and recent Auraria campus development including a public-private partnership with a hotel chain; (b) an Environmental Impact Statement drafted by CU Denver professors in the 1970s; and (c) and perceptions of the Auraria campus' ongoing community engagement (Pendergast, 2013a, 2013b, 2013c, and 2014d). Additionally, the CU Denver is involved with a current Sun Valley planning grant (United States Environmental Protection Agency, 2016). 
To contextualize the discussion of both cases, background on the roles of universities and foundations in similar roles in the United States are provided below. In urban areas like Denver, with at least twenty-six universities, campus leaders play key roles as anchor institutions. Therefore, the implications of campus investments in neighborhoods are discussed as one type of anchor institution in the case studies of this article. Foundations also play a major role in community development and their role as partners in communities is significant.

\section{Role of Universities and Foundations in Urban Planning and Development}

Both universities and foundations share the same four types of capital that influence neighborhood planning and development in a neoliberal context (Etienne, 2012; Fields, 2014): financial, intellectual, social, and political (BondGraham, 2011; Etienne, 2012; Sites, Chaskin, \& Parks, 2007; Turner et al., 2014). The sociopolitical climate creating the need for university and foundation involvement in urban development (and their types of capital) are similar. However, their perspectives as stakeholders and their self-interests are different.

Financial Capital. Universities function as knowledge economies that experience changing financial realities that require creating new practices for financing universities (Eteinne, 2012). Etienne (2012) describes the "contemporary commercialization of all aspects of urban life and higher education. Under the current paradigm of neoliberal market ideology, both town and university have pursued fulfillment of their traditionally not-for-profit missions with for-profit management schemes” (p. 1280). Universities generate revenues as students and employees consume various types of goods and services provided, such as classes, retail, other amenities, sporting events, etc. (Etienne, 2012). The current sociopolitical climate includes "talent attraction and retention... [through the work of] economic development professionals [who] are looking to colleges and universities as the instruments that will help them transform their marginal cities and regions into Silicon Valley or Route 128 [the area around Harvard University and the Massachusetts Institute of Technology]” (Etienne, 2012, p. 1401). Universities as landowners often in the urban core are sometimes described for "their economic footprint... as the new company in our 'company towns'” (Baldwin, 2017, para 25). Some universities have employees focused on hiring, purchasing, real estate development, urban revitalization, expansion, and other development (Etienne, 2012; Rapson, 2008). Purchasing and development includes, "revitalizing industrial land for academic purposes” (Etienne, 2012, p. 1116) and, "having learned lessons from urban renewal, they now 'bank' land to accommodate expansion in the years to come or, at the very least, to leverage it for resources somewhere down the road” (Etienne, 2012, p. 1433). Universities can also leverage their purchasing to support small and local minority- and womenowned business enterprises as a means of investing in community economic development resulting in wealth building for local business leaders.

Intellectual Capital. Universities as knowledge producers not only attract talented students and employees, but also historically and contemporarily "shape urban policy, planning, and economic development” (Baldwin, 2017, para. 3). For example, the 1959 amendment to Section 112 of the federal Housing Act, created a financially incentivized means for cities and universities to acquire land, relocate residents, and then support universities in developing the land utilizing federal matching funds at a ratio of 1:2 or 1:3 (local to federal dollars) (Baldwin, 2017). Universities educate students, who then occupy the policymaking, planning, development, 
and business roles in the city with the power to influence the future of cities (Baldwin, 2017; Etienne, 2012).

Social Capital. Universities have human capital in their employees and students as "their 'product'- that is, their students, who will become central actors in the knowledge economy" (Etienne, 2012, p. 190). Urban universities often have employees and students who may be of different demographics (such as race and class) than the residents of those adjacent neighborhoods with a concentration of people who are low-income and/or people of color (Etienne, 2012). Anchor institutions, like universities, university medical centers, hospitals, and sports teams, often form partnerships via civic engagement. Examples include Campus Compact, service learning, and community service programs that collaborate to problem-solve local issues such as crime with community organizations (Baldwin, 2017; Etienne, 2012; Rapson, 2008). The community engagement is useful to the university's public relations image and perception of giving back to the community (Etienne, 2012). Some anchor institutions, such as housing authorities, have regular practices of engagement with communities in their daily work and in planning for development. This is more clearly mandated and reported for public agencies, but may be less clearly visible for university development projects (Etienne, 2012).

Political Capital. Contemporary cities are strategic about drawing private investment in urban core areas that experienced deindustrialization, which resulted in the need to, "reorganize urban space to serve their interests, as industrial capital did in the nineteenth and twentieth centuries" (Etienne, 2012, p. 142). One form of reorganization includes offering universities, whether public or private a "tax-exempt status [that] allows them to invest in real estate with less risk than a private investor might face" (Etienne, 2012, p. 1425). As a result, "the most recent writing on universities as catalysts for growth is steeped in regional economic development interests" (Etienne, 2012, p. 1393). However, “the residue of higher education's role in urban renewal and in the displacement of low-income neighborhoods near campuses is still remarkably close to the surface of university-community relations" (Etienne, 2012, p. 1377), as the "displacement of hundreds of African Americans during the period of Urban Renewal in the 1950s and 1960s... Section 112 amendment of the Urban Renewal legislation of 1959 (which allowed colleges and universities to employ Urban Renewal policy for campus expansion)” (Etienne, 2012, p. 285). The, "land acquisitions for dramatic campus expansions made during the late 1960s and early 1970s displaced thousands of poor and working-poor families, many of them African American (Etienne, 2012, p. 166). As a result, the city often acquires land for university expansions because the city handling of land acquisition and relocation provides political cover for the university. "Because of their nonprofit status and geographic position as fixed capital, universities exist with the expectation that they will advance the public's interest and welfare" (Etienne, 2012, p. 1441). Local government grants university tax subsidies presumably in exchange for services, public good, and the educational mandate. This is particularly true for public land grant institutions in towns, where an expectation exists that, "campus stakeholders, neighborhood residents, and city leaders must be at the table, in an equal way, for transparent discussions about how higher-education institutions can best serve as a public good" (Baldwin, 2017, para 25). The department where the community-engaged work of universities is housed is important and may include a perception of likely co-optation if housed under senior administration who would expect a give-and take-relationship in order to support the work that may include providing political cover for university in development efforts (Etienne, 2012). As a 
result, the organizational structure and practices of universities involved in development may be critiqued for a lack of transparency and accountability regarding benefits for the community particularly if the local history included Section 112 relocations (Etienne, 2012).

\section{University Roles in Urban Neighborhood Planning and Development}

"The relationship between cities and higher education has grown more complex with time," in the context of, "regional and global restructuring of the economy [that] may have affected the neighborhoods themselves” (Etienne, 2012, p. 1079). The first federal policies in 1862 and 1890 established land-grant colleges and universities, which created the initial campus footprint for many colleges and universities (Baldwin, 2017; Etienne, 2012). The 1959 amendment to Section 112 of the Housing Act was a second similar legislation that created a means for universities to acquire land in urban renewal areas, which included the core land amassed for many urban universities in existence today (Etienne, 2012). Later iterations of public policy included the creation of public-private partnerships that stimulate the economy through public housing redevelopment programs, e.g., Housing for People Everywhere VI (HOPE VI) and Choice Neighborhoods. These last two programs do not directly relate to university land and development, but do influence both the nature of development collaborations in the neighborhoods adjacent to universities and the types of collaborations universities engage in via community engagement and research (Etienne, 2012; Walker \& East, 2014; Wilson, 1996). The culmination of these various neoliberal urban renewal interventions resulted in a larger scale, "gentrification [that] has evolved beyond the domain of small private pioneers to being something that only 'corporate gentrifiers' - developers with enough capital to invest in valorized inner-city markets - can engage in” (Etienne, 2012, p. 1063). Etienne (2012) noted,

The short-term success of urban real estate development masks the persistent problem of urban poverty that was unresolved by the New Deal policies of the 1950s and 1960s and in fact exacerbated by restructured urban economies and neoliberal public policy of the 1980s and 1990s. The fragmentation of municipal governance and services created openings for private actors to complete what public policy failed to do - make inner city neighborhoods attractive and livable. The shift of responsibility from the federal government to cash-strapped city governments created opportunities for colleges and universities to augment municipal services such as crime prevention. For better or worse, this placed the fate of urban communities in the hands of private actors who are not directly accountable to public processes and interests...many institutional leaders have suggested that universities should deepen their ties to their host communities. Those ties have taken various forms, including partner and catalyst for economic growth, collaborator in urban neighborhood revitalization projects, and provider of urban services. "Eds" and “meds" - colleges/universities and hospitals - are often cited as potential factors in the revival of urban economies and communities. In the past two decades, higher education and health care have become two of the largest sources of employment in contemporary urban economies (p. 182). 
Foundation Roles in Neighborhood Planning and Development

Foundations' use of financial, intellectual, social and political capital for urban development varies from foundation to foundation and project to project. Some community foundations, like the Chicago Community Trust, explicitly identify as anchor institutions. The Casey Foundation is a collaborator in anchor work, but does not consider itself an anchor institution. The Ford Foundation, Casey Foundation, MacArthur Foundation, Enterprise Community Partners, and other local foundations often function as catalysts for transforming concentrated poverty neighborhoods within the United States (Turner et al., 2014). Public housing reform since the 1990s has also included neoliberal market and policy approaches that incentivize public and private investment in urban neighborhoods that previously experienced decades of disinvestment (Edmondson \& Hecht, 2014; Fields, 2014; Howell, 2016). These public-private relationships have used federal funding that mandated securing local engagement and support from individual residents and sometimes community-based partnerships as stakeholders (Bond Graham, 2011; Sites, Chaskin, \& Parks, 2007).

Private foundations play a role that focuses on a collective impact, addressing complex issues in local communities. Collaboration across various sectors builds on assets, strengths, and resources (Edmondson \& Hecht, 2014). Local foundations, city offices, and CBOs sometimes collaborate to convene local planning processes and approaches. These collaborations support an empowerment process for residents that works within contemporary market-based public housing redevelopment approaches (Fields, 2014; Howell, 2016). Market-based approaches to public housing redevelopment are similar to university approaches that include public-private partnerships that incentivize private companies to redevelop with tax breaks, low interest loans, and less regulation, which, some deem, amounts to public subsidies for private development (Squires, 1989). Local support includes private foundation funds that develop the capacity of local CBOs while simultaneously helping foundations accomplish their organizational vision, such as investing in improved outcomes for low-income families (Fields, 2014). As a result, foundations may play a role in convening forces driving and resisting the development of mixedincome communities near public transit stops that often connect to local universities as key anchor institutions. Some foundations seek to level the playing field between stakeholders with different experiences of power and competing interests in order to work towards defining common goals. However, the work is inherently complicated and subject to multiple, sometimes contested, interpretations. Partnerships can create both strengths and limitations for resident engagement, depending on the role, structure, and capacity of the various partners. Universities as anchor institutions have a significant amount of power and capital (as explained above) and therefore can learn community engagement lessons by informing themselves of public housing redevelopment critiques of foundation roles.

Fields (2014) critiques foundation collective impact approaches in urban development contexts, and states that while collaboration may help, the goal should be to

fundamentally transform social, political, and economic structures... urban community organizations are not contending with the effects of disinvestment so much as the consequences of opening 'underserved' central-city markets to mobile and underregulated global capital... Contesting the social costs of capitalism to working class and 
marginalized peoples calls for new political strategies and rescaled forms of activism based on an analysis of power relations that moves beyond the local. (p. 146)

In urban redevelopment contexts, foundation funding may result in engaging with many historic and contemporary community groups. Some groups utilize conflict-based community organizing approaches that contest neighborhood disparities yet rely on foundation funding to become, "enmeshed with the state and market structures they once resisted" (Fields, 2014, p. 146). The enmeshment of CBOs in processes seeking to develop support for neighborhood redevelopment may be a form of bureaucratizing, co-opting, or repressing resident resistance to the sudden financial interests in their formerly disinvested communities (Chrisman, 2010). The CBOs working in these neighborhoods are then part of mainstream processes with a structure established by those with financial, intellectual, and social capital.

The community development role of foundations, local governments, public works departments, and local CBOs is to act as place based anchor institutions (Birch, Perry, Taylor, 2013; Mazany \& Perry, 2014). Foundations are asked to lead in the context of a local government that is less resourced from the federal government (Birch, Perry, Taylor, 2013; Mazany \& Perry, 2014). Place-based community foundation leadership is asked to create solutions to local social issues and infrastructural problems unaddressed by the public or private systems (Birch, Perry, Taylor, 2013; Mazany \& Perry, 2014; Nye \& Glickman, 1998). Neighborhood redevelopment is one issue foundations focus on, due to the combination of neighborhood problems in communities they are invested in, as well as the demand for central city land due to forces of globalization, investments in regional transportation infrastructure, and migration of people to cities (Birch, Perry, Taylor, 2013; Mazany \& Perry, 2014). Redevelopments rely on the collective missions, available resources, and relationships of public-private partnerships (Birch, Perry, Taylor, 2013; Mazany \& Perry, 2014). Foundation capital has the ability to leverage and build on local assets (BondGraham, 2011; Turner et al., 2014). Foundations, private institutions, and non-profit organizations often partner with government entities to offer financial, intellectual, social, and political capital focused on a shared agenda seeking to facilitate social change; however, many community organizations are skeptical of collaborating with public-private partnerships (BondGraham, 2011; Sites, Chaskin, \& Parks, 2007; Turner et al., 2014).

\section{Community Organizing Skepticism in Public-Private Partnerships}

Community based organizations that use community organizing methods, such as building power bases in institutions that include people who experience marginalization, are often solicited to become part of urban redevelopment planning. Community-based organization participation in community development is often a measure of effective engagement in capacity building efforts (Birch, Perry, Taylor, 2013; Nye \& Glickman, 1998). Community foundations often list community organizing as a component of capacity building; however, community organizing, community development, and social planning processes have different models, tactics, engagement strategies and outcomes (Lowe, 1998). Community organizing groups may or may not agree with the goals of Community Development Corporations and social planning processes (Lowe, 1998). Rather, community organizing based groups more often have a stake in specific solutions and are focused on gaining power within unequal partnerships known to benefit private developers (Mazany \& Perry, 2014; Squires, 1989). 
Demand for land that was once ignored drives urban renewal in a climate of deregulation, which community organizing processes deem a key moment to mobilize people to take action (Chrisman, 2010; Squires, 1989). Many redeveloping neighborhood residents have already lived through nearby development since 1960s and more recent public-private partnerships (Etienne, 2012). Community organizing groups have their own self-interest in naming and engaging in the conflict and struggle redevelopment brings, and therefore they seek to think critically regarding prior development history (Allen, 1970). For example, some black leaders or more radical movements became token representatives who may have been co-opted into providing support for the capitalist agenda of their neighborhoods (Allen, 1970). War on Poverty programs funded engagement in community processes, which both built political power of minority groups to produce enough votes and candidates to African American mayors, as well as create the Congressional Black Caucus in 1976 (Chrisman, 2010). Community organizing groups are often skeptical of the erasure or dilution of their requests in false consensus processes that may never meet public need (Mazany \& Perry, 2014; Squires, 1989).

\section{Tensions Inherent in University Partnerships for Community Development}

University community development efforts have similar critiques as foundations and public community planning and development efforts co-opting community organizing groups. In a neoliberal policy context, developers often have for profit and non-profit arms of their organizations that conduct the business and public relations of developments (Allen, 1970; Mazany \& Perry, 2014). Universities have been critiqued for having a similar parallel neoliberal structure:

the relationship between cities and universities is historically one of convergence... convergence has roots in the contemporary commercialization of all aspects of urban life and higher education. Under the current paradigm of neoliberal market ideology, both town and university have pursued fulfillment of their traditionally not-for-profit missions with for-profit management schemes (Etienne, 2012, p. 1280).

The simultaneous campus development and community engagement processes risk placing university civic engagement as a form of “community relations as a part of expansion and development exposes the co-opting of the language of participation, representation, collaboration, and community development by university leaders to serve the interests of the research-extensive university” (Etienne, 2012, p. 1460). The processes parallel the role CBOs are asked to play in development processes. As a result of the urban renewal history, and the current trends in urban redevelopment, community organizing and university civic engagement can play an important role in public-private partnerships and yet must recognize the potential to be coopted by competing interests that favor private development (Allen, 1970; Etienne, 2014).

\section{Methods}

For the first case study, the detailed contextual information about the neighborhoods, the Resident Advisory Council process, as well as the methods including the research design, participant characteristics and sampling, data collection process, and data analysis appear in 
Walker \& East (2014), who noted:

Data were collected and triangulated from multiple sources, including semi-structured interviews, participant observation by the first author, field notes, and artifacts including audiovisual materials (e-mails, messages, photographs, local newspaper media, and city council public hearing video footage), official memos, meeting notes, meeting minutes, and additional records from the process. (Walker \& East, 2014, p. 348)

The Institutional Review Board at the University of Denver approved the research. The twentysix interviewees included non-profit, foundation, and public employee professionals, as well as residents of various demographics and standpoints (including public housing residents and homeowners who are neighborhood association leaders (often homeowners) and Local Resident Council (public housing leaders) for both neighborhoods.

The second case was based on a review of Auraria campus documents related to the development or engagement in development in the two neighborhoods of this study. These include documents between 2006 and 2016: (a) coverage of scholarships for displaced Aurarians (Brown, 2006); (b) additional planning documents of the Auraria Higher Education Center to develop campus buildings and a public-private hotel partnership "where Metro students used to play tennis” (Pendergast, 2013b, para. 2), as well as expand athletic fields into the La Alma/Lincoln Park neighborhood (AHEC, 2012 as cited in Pendergast, 2013b; Metropolitan State University of Denver, 2016; Pendergast, 2013a, 2013b, 2013c, and 2013d); (c) University of Colorado Denver, foundation, and federal funding for ongoing planning in Sun Valley (United States Environmental Protection Agency, 2016; Vaccarelli, 2016); and (d) coverage of the Broncos stadium and housing authority as anchor institutions in the Sun Valley development (Roberts, 2016).

\section{Results and Discussion}

The results from the two cases are presented with the data for the RAC first, followed by data from the reports and documents of the Auraria planning processes. The main themes summarizing the role of the foundation in the qualitative interviews include: (a) providing financial resources; (b) building capacity; (c) engaging in relationships; (d) designing a process; (e) hiring a neutral facilitator; and (f) functioning as a key partner with city economic development staff, CBOs, and residents. Each of the themes is described in-depth below with comparisons across the neighborhoods and triangulating RAC artifacts or member checking when possible. For the sake of brevity, translation and application to the Auraria campus, these results were added to each of the RAC result themes.

\section{Providing Financial Resources}

RAC Collaboration. Professionals described MC-D as the convener of the RAC process as they sought to transform the way city system operated. MC-D worked with the Office of Economic Development to secure the funding for the RAC process from the Casey Foundation and the City and County of Denver. MC-D also provided logistical resources, such as language translators, 
food served during meetings, filling in gaps in roles not performed by other collaborators, taking meeting minutes, and documenting the planning and RAC processes. The La Alma/Lincoln Park resident participants in the interviews were not clear on MC-D's resource role in the RAC process. For example, one participant said, “Well, I'm not really sure. I don't remember their active presence in those meetings. I guess I'm not sure what their role was." Sun Valley participants were also not clear on MC-D's role, but they discussed how MC-D set up a peer visit trip to Portland that enabled them to experience mixed-income redevelopments and transitoriented development. One Sun Valley participant described their experience seeing the HOPE VI redevelopment at New Columbia for the first time:

Those redeveloped neighborhoods in Portland were pretty impressive. You couldn't tell what was public housing. The areas were so nice. They said some of them paid a lot of money to be in those places and other people paid minimal. It works. You wouldn't think it would until you went up there and you saw it, but it works.

The neighborhood city council person suggested the peer visit to the RAC professional and resident participants during a related community organizing meeting in the spring of 2008 after the RAC process was complete. The peer visit to Portland, Oregon occurred in July 2008 and was funded by MC-D at the request of community leaders. The peer visit included two homeowners, a community organizer, a housing authority redevelopment staff member, and three city employees (Office of Economic Development, the transit-oriented development program manager, and a City Planning staff). The participants traveled around Portland on public transportation to experience transit-oriented developments and build relationships with each other and similar stakeholders in Portland. The transit-oriented development manager was especially appreciative of the chance to learn alongside the Sun Valley CBO, as he wrote in an email, "It was not only informative from a transit-oriented development perspective, but I found hearing the residents and community organizer’s perspectives also very beneficial."

Auraria Campus Application. Etienne (2012) wrote about resident resistance to university residence halls built within neighborhoods, which may be a transferable learning from the peer visits to housing sites after the RAC process. The La Alma/Lincoln Park neighborhood in 2000 fought against residence halls in the neighborhood, which may have been overcome with a similar peer visit engagement processes (Pendergast, 2013a).

Building Capacity

RAC Collaboration. MC-D also played a role in bringing residents to the RAC table to support them, make them feel welcome, and empower them to take control of the impact of the redevelopment on their lives. RAC professionals describe how MC-D feared that redevelopment was going to be an issue in Sun Valley and La Alma/Lincoln Park because MC-D wanted to build the capacity of the neighborhoods. An MC-D employee said:

The more I thought about it, I realized I need to bring this back to MC-D because when we were talking about... what we were supposed to be doing... making sure that these neighborhoods are building their capacity and are successful. You know, one of those pieces isn't gonna happen if most of the neighborhood is displaced... long term, MC-D 
can't say we were successful. So really it became clear to me that this was gonna be an advocacy issue that we need to be involved in.

Another professional described MC-D’s commitment to the RAC process:

They were really committed to finding a way to make it work in spite of a lot of people's concerns, legitimate concerns, and legitimate anger about past promises not kept and things like that. I'd say MC-D was really kind of the entity that said we have to make this work for the benefit of the residents we just have to make this work.

MC-D tried to represent the residents in the planning group and humanized organizers to the city behind the scenes. MC-D staff described their perception of community organizing among city staff:

There was a lot fear around what organizers do, and that they might be just instigating... they're just going to rile everybody up, it's going to be anarchy. I did a lot of work around just talking about what organizers do, and the organizing groups would meet with MC-D, we would talk through issues.

A city planner stated that MC-D’s role was to

Keep the city on their toes. And to be the voice for the residents and the community. Honestly, they really were skeptical and questioned the city's and Denver Housing Authority's motivations. I think they questioned the intent and they also questioned the process.

Public housing residents in La Alma/Lincoln Park remained engaged in the city's South Lincoln Steering Committee through at least 2012. Residents of Sun Valley remained engaged in the planning processes until the plan was adopted in 2013 and into the ongoing planning processes in 2016 (Roberts, 2016; United States Environmental Protection Agency, 2016). Therefore resident capacity was not only supported, but also extended at least nine years past the initial RAC process. As a result, the resident engagement and capacity was strong at least a few years after the Casey Foundation closed out their planned funding the 10-year MC-D initiative.

Auraria Campus Application. The Auraria campus, like many campuses, similarly has to manage the displaced Aurarian's historic and current skepticism regarding the university's intentions and willingness to ensure that residents benefit from university development (Etienne, 2012; Pendergast, 2013b). The Auraria campus made commitments to the displaced residents, including Displaced Aurarian Scholarships that required ongoing engagement and preparation to begin implementing in the 1990s (Brown, 2006). The University of Colorado - Denver is a key collaborator with the ongoing Sun Valley planning (funded by the federal government) that includes partnering with Enterprise Community Foundation, the Byrne Criminal Justice Innovation Program, and local collaborators (United States Environmental Protection Agency, 2016; Vaccarelli, 2016). The Auraria campus has also engaged the La Alma/Lincoln Park residents in pedestrian amenity improvement planning, as well as a community benefits process with the new athletic fields within the neighborhood (AHEC, 2012 cited in Pendergast, 2013b). 
Relationships

RAC Collaboration. The RAC professionals worked with the MC-D foundation to perform a function that included engaging in relationships with both residents and the CBOs working in the neighborhoods. The MC-D resident coordinator also spent a lot of time trying to get residents to come to meetings and said:

Initially in the process... I think that the City came in and thought - DHA maybe too thought - okay, great, we're just gonna have Front Range Economic Security Center, Metro Organizations for People, Project Wise, and MC-D just do all the outreach for us... And quickly we came to the recognition that no this is going to be a coordinated effort.

Another study participant said MC-D relationships helped get the various groups to work together:

The best way that can be invested is really living up to its name making those connections. Connecting the expertise with the institutions and developing the best, most effective and efficient strategies available. Keeping the connections with the collaborative agencies like the non-profits, like Project Wise and Front Range Economic Security Center and Metro Organizations for People and being a face that is liked by the community, by the residents.

Despite MC-D’s best efforts to activate their professional networks, CBO stakeholders that helped support community residents were reticent to get involved. Yet, Sun Valley residents, as the most hesitant in the process, did participate not just in local events but also in national venues such as the September 2010 Partners for Innovation National Symposium and Policy Forum that discussed transit-oriented development, affordable housing, and community perspectives. Sun Valley residents also initiated having their voices and experiences heard during a mayoral candidate forum their community based organization hosted in April 2011, which demonstrated their initiating relationships with potential elected city officials. Then-City Council member, Michael Hancock, engaged with residents through the forum before he became mayor. Sun Valley residents also engaged in mediation for conflict resolution among historic leaders, which was funded by the MC-D and resulted in residents' abilities to set clear boundaries on daily interactions with one another and within CBO meetings.

La Alma/Lincoln Park RAC participants maintained relationships with key planning and redevelopment staff. This resulted in planning the Mariposa redevelopment with resident oversight and the development of a healthy public housing development tool in 2010. All three CBOs involved in the RAC process had an ongoing role in the resident and professional relational networks developed during the RAC process, which resulted in ongoing social support and safe spaces to discuss redevelopment implications, as well ongoing involvement in organizing for resident self-interests within the context of regional changes. 
Auraria Campus Application. Initially, Auraria campus community relationships were contentious and punctuated by legal battles regarding home and business owner displacement (Pendergast, 2013c). Many of the residents had live-work style arrangements for their homes and many of the businesses did not reopen after their displacement (Pendergast, 2013d). Archive photos of the neighborhood homes are similar to the single family homes in the La Alma/Lincoln Park and Sun Valley neighborhoods, which is aligned with the reality that many displaced residents moved within the La Alma/Lincoln Park neighborhood (Pendergast, 2013d). Universities utilizing urban renewal to develop university footprints should consider that displaced residents might still be neighbors of the campus after displacement (Pendergast, 2013c). An Environmental Impact Statement (EIS) drafted by two University of Colorado Denver professors in the 1970s noted that six years into the campus construction (likely around the time of the campus opening) no La Alma/Lincoln Park resident representatives were on the Auraria Higher Education Center (AHEC) board, which was a concern (AHEC, 2012 as cited in Pendergast, 2013b; Pendergast, 2013c). The EIS noted the contentious relationships with 'radical' Latino/Latina activists and strongly encouraged AHEC to proactively engage with residents (Pendergast, 2013c).

\section{Creating Structure: Process Design}

$R A C$ Collaboration. Process design refers to the role of the foundation in making sure that a process was enacted in a manner that equally engaged all stakeholders. The National Civic League (NCL) contracted to provide the RAC facilitation and helped the planning team create a community input process that would keep people at the table with transparency and integrity. The NCL explained:

Public processes go one of two formats, you either go town hall or focus group. When you go to town hall that's basically an open mic for community residents, you have a public official speaking at the people, not with the people, and then you have residents unloading at them, and people are frustrated. And then you have the focus group where there's no public official sharing information, you're just gathering wish list items, and then focus group information often gets kicked to the side and never acted on. And so people also get frustrated with process because in either scenario there's not really a rich give and take, and the way that the League designs processes it has to be the holders of power sitting at the table with the people in conversation, in actual dialogue. My job was to design the processes that we would use for all of those things, but then also do all of the diplomacy required so you address everyone's concerns.

The RAC participants did not comment in their interviews on the process design directly, although several RAC participants from both neighborhoods alluded to the fact that the process felt like "a dog and pony show," "a political sandbox," and "a show with an entertainer." The NCL suggested leaving the residents out of the process design stage despite the CBO's typical practice of bringing residents to decision-making tables to speak for themselves. CBO professionals expressed concern that the decision to have professionals design a process for residents resulted in the NCL designing a process that either was not explained clearly and therefore not transparent, or that did not have integrity for residents any more than previous planning processes did. 
A component of the process design was creating a structure where MC-D was the initial convener. MC-D conducted outreach to city offices and Denver Housing Authority and invited them to the table with CBOs to discuss redevelopment and planning. MC-D initially facilitated meetings, and then decided they needed to hire a facilitator to manage relationships and be cheerleaders of the process even in the midst of conflict. For example, one professional said:

I am not a regular actor in that inter-agency environment, so I don't know what the vote on the street is. So as flare-ups would occur, it would really be MC-D that I would sit down... and figure out what the people were mad about and how we could address it. You know, what do we need to do for people to feel like their concern has been heard? What adjustments do we need to make to the process to get people's belief in its integrity restored... If there hadn’t been MC-D staff there wouldn't have been a process.

The La Alma/Lincoln Park participants observed MC-D being part of the process design. They reported seeing MC-D staff serving food and playing a clerical role, such as taking notes, typing documents, and calling residents if something came up. Sun Valley participants did not observe MC-D creating structure for the RAC process. The community organizer working with the Sun Valley residents would explain the meetings and processes that MC-D, the NCL, city employees, and community based organization staff held; however, the Sun Valley residents were used to working directly with these employees and calling and structuring meetings themselves in the organizing work MC-D funded, so they did not acknowledge or credit MC-D with creating the RAC structure. The Sun Valley residents were instead critics of the RAC process design and structure and described the meetings as a waste of their time and a distraction from the work they defined as urgent and important.

Auraria Campus Application. Critiques of the Auraria campus describe verbal commitments made in the 1970s to residents stating the land would not be used for commercial development and that the campus footprint would not expand south of Colfax Avenue (Pendergast, 2013a). The RAC model could give residents a structure to discuss these past promises in the context of current projects. The Auraria campus 2012 plan notes an intention for ongoing public-private partnerships (Pendergast, 2013a; AHEC, 2012 as cited in Pendergast, 2013b). The campus leaders might consider involving the Auraria campus employees and students in the process with neighborhood residents. Faculty are required to complete service to the campus and community, which could include creating service learning or internship opportunities for relevant classes. Students in social work, city planning, political science, business, and law clinic or mediation focused majors could complete course and program learning objectives with hands-on experiences in engaging with residents one-on-one and in meetings. The campus involvement in dialogues with residents could improve university and neighborhood relationships (Etienne, 2012).

Hiring a Neutral Facilitator

RAC Collaboration. The NCL was hired to provide a neutral facilitator. The facilitator was a Latino male who was bilingual in English and Spanish. The RAC professionals and participants agreed that the function of the NCL facilitation was objectivity. MC-D and CBOs were 
concerned for residents and therefore viewed as not objective. The residents had their selfinterests and the city already had a general vision for transit-oriented development for the neighborhoods. The professional participants in the interviews stated that they learned early in the process that MC-D could not facilitate and manage the process. The NCL was brought in as "an objective facilitator" because they did not have a stake in the outcomes whether that be development, non-profit outcomes, or being on the city payroll full-time.

The NCL was described as setting an equal table that gave all of the various perspectives a chance to respond. The facilitator captured everyone's opinion and directed participants development of ideas and input for future meetings. The RAC participants described the facilitator as: (a) neutral referee for a good clean fight that enabled full participation (rather than having to referee themselves); (b) a timekeeper; and (c) a used car salesman and an entertainer. RAC professionals stated the facilitator was able to work to understand the behind the scenes dynamics, but critiqued the facilitator's ability to manage various city employee dynamics and perspectives.

The NCL facilitator therefore tried to design a process that allowed all of these interests to dialogue regarding community perspectives at an equal table with focused meetings. The facilitator drew out ideas and residents ability to express their hopes and vision for the future of the neighborhood. One La Alma/Lincoln Park participant described how the NLC engaged residents:

The way that they induced people to come up with opinions with the sticky notes I think was actually a good idea because you get a wider response from everyone when you do that. If you just ask questions and have everyone respond in a typical question and answer session you're gonna get the strong personalities only, and I think you need to get all the personalities, or at least an opportunity for all the personalities to respond.

Another participant said, "he really encouraged people to speak up and to participate... they would give us homework, but it really wasn't homework, it was just to get your mind working so at the next meeting you'd have ideas and input.” A third resident described the process of documenting the discussion as dream it up and sum it up. They would, “capture everybody's thoughts and opinion and then... tried to put them concisely down for us. Put them into a language that the city could understand."

The professionals described the NCL facilitation as an effort to keep people at the table equal and focused on future neighborhood change. The facilitator stated,

I got to be, by virtue of having a neutral referee for the process, I think it creates a space where people can feel more free to participate instead of feeling like they have to be the referee. And ultimately they can't be the referee because everyone is acting from their own self-interest and our self-interest is to have a good clean fight. (laughter) Go to your corners, come out when the bell rings, you know. (laughter) 
La Alma/Lincoln Park participants also described the facilitation as, "running the show.” One La Alma/Lincoln Park participant described their perception of the dynamic as the facilitator tried to keep the interactions light-hearted:

He’s like a car sales person. He was our entertainer... It wasn’t my style, but he was very good... He's a little too raw. I think he was doing cartwheels. And I'm just jealous because I can’t do those anymore. He’s a little bit too 'college.' ...A little childish. A little bit unprofessional. Maybe he was 'dumbing' it down because we're the lower economic... Is this guy acting like this because he thinks we're all economically deprived or what? Or is this just how he is? Would he do this in a corporate boardroom?

Sun Valley participants noted that the facilitator respected everyone involved including the residents and seemed to understand the behind the scenes topics they discussed. A Sun Valley resident described the facilitator role as:

I think he was just brought in to try and run the meeting, but sometimes I don't think he did run it...They still had other people from the city come in and stand there and tell him basically, what to do, what to say. The city planner was always there in the middle of everything.

The Sun Valley CBO leaders had years of capacity-building funded by MC-D, which included community organizing training that gave Sun Valley resident leaders the confidence to name the power dynamics they observed in the RAC meetings. Some Sun Valley residents felt the RAC process was co-opting their organization, which they perceived as powerful and effective. The neighborhood leaders saw themselves as effective leaders of meetings that regularly challenged city employees (such as city planners) in their organizing processes and did not see the need to have a facilitator lead the process. In contrast, one professional also commented on the facilitator, stating that he erred on the side of listening to the resident perspectives and did not know the city departments:

As a facilitator, he could have done a little better job of understanding the City of Denver departments and process and the different departments and agencies within in the city and just the planning process. In the end he did. I think it's done him well. He's gotten more work with the city. I felt like sometimes he is a little bit biased toward the organizers and the residents. Which is probably fine. Facilitators tend to be more biased to the people.

As a result, perhaps the city planner also felt like their process was co-opted, which is why she consistently directed him as the facilitator. The perception that the NCL facilitator was biased toward any group or had the self-interest of securing future work with the city calls the perception of his 'neutral facilitator' objectivity into question.

Auraria Campus Application. The Auraria campus coalition efforts to create pedestrian and social connections can learn from the resident hesitancy and the need for coordinated outreach. Similarly, the displaced Aurarian and La Alma/Lincoln Park requests for community benefits included access to campus amenities like athletic fields. The EIS suggested that the campus 
make athletic fields available to neighborhood residents came to fruition in the 2015 development (Metropolitan State University of Denver, 2016; Pendergast, 2013c; AHEC, 2012 as cited in Pendergast, 2013b). Auraria Campus had purchased thirteen acres of land in the La Alma/Lincoln Park neighborhood 2008 to develop the athletic fields in order to repurpose the space of the athletic fields in the initial campus footprint for a public-private partnership (AHEC, 2012 as cited in Pendergast, 2013b). The campus planners and administration envisioned specific land as public-private partnerships as revenue generating properties. However, the demands of the market did not align with initial plans (AHEC, 2012 as cited in Pendergast, 2013b). A Connect Auraria Coalition was formed in 2010 to develop a vision for physical and social connections between the campus and the surrounding neighborhoods, which included the La Alma/Lincoln Park Neighborhood Association, the Pepsi Center (sports stadium anchor), and similar public representatives as the RAC process (AHEC, 2012 as cited in Pendergast, 2013b). Physical connection improvements recommended by the coalition were funded by the Denver Regional Council of Governments and the City and County of Denver by 2012 and included pedestrian improvements for two La Alma/Lincoln Park intersections with the campus (AHEC, 2012 as cited in Pendergast, 2013b). The Connect Auraria Coalition worked with the neighborhood association comprised more of White middle-class gentrifiers, but did not reportedly engage the public-housing resident structures. Including the Local Resident Council and the redevelopment Steering Committee might have resulted in different perspectives of lower income parents that rely on public transportation and pedestrian amenities with their young children, who may have different perspectives on the proposed pedestrian amenity improvements.

Functioning as a Key Partner with the City

RAC Collaboration. The final foundation role in the RAC process included functioning as a key partner with the Office of Economic Development staff, CBOs, and residents. A MC-D staff member described how a city Office of Economic Development staff member described MC-Ds role as a key partner with the city both since the inception of MC-D and in the RAC process stating:

'You should be at the table ... you need to make sure that resident voices are being heard' ... the Office of Economic Development was the entity that saw that the politics were going to make it difficult for the process to move forward with everyone self governing, so they reached out to us and asked us to develop a game plan for moving everybody forward... we received critical political cover from Office of Economic Development to legitimize our efforts while the City and others that were applying pressure to the City Planning Department to keep it moving... and to say no, we're doing this. This has to happen. We need to give people time to really have thoughtful input into what's going on.

The Office of Economic Development had a history of investing the neighborhood CBOs via local small grants. The Office of Economic Development also had a future role in implementing Station Area Plans via supporting infrastructure, drawing commerce, and increasing job access as components of creating economically thriving neighborhoods around light rail stops. The Office of Economic Development was described as political cover for MC-D’s efforts. The RAC 
participants did not understand the Office of Economic Development's role in the RAC and redevelopment process. Yet, organizers working for CBOs participating in the RAC processand in other neighborhoods within the Denver metropolitan region after the RAC processreported a lack of city engagement with residents or a more tokenizing level of engagement in similar planning processes without an RAC process. Therefore the key partnerships between the Office of Economic Development and MC-D may have provided the political cover needed to get residents a voice via the RAC process.

Auraria Campus Application. Eteinne (2012) describes a similar political cover that community engagement initiatives of universities play for the institutions development agendas. The 2012 AHEC Master Plan describes almost 45,000 students and a 150-acre campus that includes property acquired after the initial urban renewal acquisition of land (AHEC, 2012 as cited in Pendergast, 2013b). The master plan includes detailed notes regarding each building location, plans for shifting purposes, and the many complicated components to consider for development of that property (AHEC, 2012 as cited in Pendergast, 2013b). As the Auraria Master Plan noted, Pepsi Center event traffic relied on the campus street grid to such a degree that the city would not allow the campus to eliminate a specific street during recent development planning. This wrinkle demonstrates the impact of sports stadiums as anchor institutions on other anchor institutions like adjacent universities (AHEC, 2012 as cited in Pendergast, 2013b).

The Auraria campus recently completed the development of: (a) the Auraria Science Building addition and renovation in 2009 and 2010; (b) a \$62 million student services building for Metropolitan State University of Denver (MSU Denver) in 2012; (c) a \$65 million student services building in 2013 for the University of Colorado Denver (CU Denver); (d) a \$40 million student services building for the Community College of Denver (CCD) in 2013; (e) a publicprivate partnership in the SpringHill Suites Hotel opened in 2012; and (f) the \$24 million Regency Athletic Complex in 2015 (Metropolitan State University of Denver, 2016; Pendergast, 2013a). MSU Denver invested \$10 million in renovations and CCD and CU Denver also had plans for renovations of undisclosed dollar amounts (AHEC, 2012 as cited in Pendergast, 2013b). The campus has over 5 million square feet of developable land remaining on campus (AHEC, 2012 as cited in Pendergast, 2013b). The Auraria campus has engaged La Alma/Lincoln Park residents when their development plans involve properties at the edges of, or are within, the neighborhood; however, a higher level of engagement includes having a La Alma/Lincoln Park resident representative on the Auraria Higher Education Center board as a means of ongoing transparent and accountable development (Etienne, 2012; Pendergast, 2013c). Veronica Barela is a Governor appointed member of the AHEC Board, who was raised in North Lincoln public housing site and has lead a local Community Development Corporation called NEWSED since 1977, serves with a neighborhood perspective and is very engaged in the community and housing (AHEC, 2018).

\section{Conclusion}

Neoliberalism and globalization with private actors as developers of formerly public land can create a civic vacuum where universities as anchor institutions, who are mission and research driven, can invest in capital, relationships, research, and programs to serve the local neighborhood (Etienne, 2012; Fields, 2014; The Democracy Collaborative, 2013). However, the 
political tools available to universities to develop their campuses have historic and contemporary barriers to engagement rooted in experiences of race and class (such as minority resident home and business displacement to establish the campus) (Etienne, 2012). The Resident Advisory Council model and the lessons learned in the evaluation process, as well as other case studies of university developments, can provide lessons learned for other anchor institutions (Etienne, 2012).

Regional forces for contemporary development, including light rail, public housing redevelopment, and campus expansion, to spur market-driven reinvestment in neighborhoods can often overpower or co-opt resident voices and initiatives for change (Allen, 2970; Chrisman, 2010; Fields, 2014). Resident engagement in lengthy planning initiatives can result in relying on the private market to execute resident suggestions, which may be, "organized by the tastes of incoming groups and not around the material and social realities of those communities" (Etienne, 2012, p. 939). For example, in the Sun Valley neighborhood, the residents' vision for an international market intended for low-income multicultural residents, and the desire for low-end retail like dollar stores, may give way to the \$351 million entertainment district constructed around the Denver Broncos Stadium and their fans as an anchor institution and customer base (Roberts, 2016). Neighborhood investments in addressing crime may also underestimate the amount of crime the entertainment district will add to the residential area (Vaccarelli, 2016). Etienne (2012) notes issues with crime generally in neighborhoods adjacent to urban universities, which at least in part stems from college students consuming alcohol within the surrounding neighborhoods that may parallel the professional sports fans' behavior that increases neighborhood crime. The regional investments in the light rail, related infrastructure, and the expected housing market boom seek to convert the higher income customer base of football fans, who typically only interact with the neighborhood approximately fifteen days per year, into new residents and consumers of business services on a more daily basis (Birch, Perry, Taylor, 2013; Mazany \& Perry, 2014).

The question remains: will foundations or other anchor institutions continue investing in hearing resident experiences during and after the redevelopment, as the racial and economic demographics in the neighborhood shift on a more daily basis, or will the outcomes fall out according to the private market? The risk of sudden interest in previously disinvested neighborhoods in a deregulated neoliberal context is high (Chrisman, 2010; Squires, 1989). The investment in and with anchor institutions could include formal neighborhood and university advisory groups with resident seats in addition to ongoing funding of grassroots community organizing driven by resident experiences over time (Allen, 1970). How can we as university leaders ensure our mission driven university intellectual, social, political, and financial capital effectively engages the communities surrounding our campuses in order to contribute to developing more just and inclusive urban neighborhoods than we inherited (Etienne, 2012)? 


\section{References}

Allen, R. L. (1970). Black Awakening in Capitalist America: An Analytic History. Garden City, New York: Anchor Books.

Auraria Higher Education Council. (2018). Auraria Board of Directors. Retrieved from https://www.ahec.edu/about-auraria-campus/board-of-directors/board-members/

Baldwin, D. L. (2017). When universities swallow cities. The Chronicle Review. Retrieved from http://www.chronicle.com/section/The-Chronicle-Review/41.

Birch, E., Perry, D. C., Taylor, H. L., Jr. (2013, June). Universities as anchor institutions. Journal of Higher Education Outreach and Engagement, 17(3), 7-13. Retrieved from http://openjournals.libs.uga.edu/index.php/jheoe/article/view/1035/680

BondGraham, D. (2011). Building the new New Orleans: Foundation and NGO power. Review of Black Political Economy, 38(4), 279-309. https://doi.org/10.1007/s12114-010-9081-z

Chrisman, R. (2010). On Robert L. Allen’s “Black Awakening in Capitalist America”: The Black middle class forty years after. The Black Scholar, 40(2), 49-53.

https://doi.org/10.1080/00064246.2010.11728714

Brown, J. (2006). Kids of “displaced Aurarians” find campus life bittersweet. Retrieved from https://www.denverpost.com/2006/01/29/kids-of-displaced-aurarians-find-campus-lifebittersweet/.

Edmondson, J., \& Hecht, B. (2014, Fall). Defining quality collective impact. Stanford Social Innovation Review, 12(4), 6-7. Retrieved from https://ssir.org/articles/entry/defining_quality_collective_impact

Etienne, H. F. (2012). Pushing Back the Gates: Neighborhood Perspectives on University-Driven Revitalization in West Philadelphia. Philadelphia: Temple University Press. [electronic book].

Fields, D. (2014). Contesting the financialization of urban space: Community organizations and the struggle to preserve affordable rental housing in New York City. Journal of Urban Affairs, 37(2), 144-165. https://doi.org/10.1111/juaf.12098

Funders Network. (2017, September 13). Anchored in Place: How Funders Are Helping Anchor Institutions Strengthen Local Economies. Retrieved from https://www.fundersnetwork.org/event/anchored-in-place-how-funders-are-helping-anchorinstitutions-strengthen-local-economies/

Glickman, N. J. \& Servon, L. J. (1998). More than bricks and sticks: Five components of community development corporation capacity. New Brunswick, NJ: Center for Urban Policy Research. 
Glickman, N. J. \& Servon, L. J. (2000). By the numbers: Measuring community development corporations' capacity. Housing Policy Debate, 9(3), 437-539.

https://doi.org/10.1080/10511482.1998.9521306

Howell, K. (2016). Building empowerment in market-based redevelopment: changing paradigms for affordable housing and community development in Washington, DC. Community Development Journal, 52(4), 1-18. https://doi.org/10.1093/cdj/bsv069

Lowe, J. S. (1998). Building community development capacity in Cleveland. A report to the Ford Foundation. New Brunswick, NJ: Center for Urban Policy Research. Retrieved from http://cupr.rutgers.edu/wp-content/uploads/2014/08/Report6.pdf

Mazany, T. \& Perry, D.C. (2014). Here for Good: Community Foundations and the Changes of the $21^{\text {st }}$ Century. Routledge/Taylor \& Francis Group: New York.

Metropolitan State University of Denver. (2016). Regency Athletic Complex. Retrieved from http://roadrunnersathletics.com/facilities/?id=1.

Pendergast, A. (2013a). Looking at Auraria's future while studying lessons of its past. Retrieved from http://www.westword.com/news/looking-to-aurarias-future-while-studying-the-lessons-ofits-past-5119749.

Pendergast, A. (2013b). Auraria campus expansion: See plans for new athletic fields and more. Retrieved from http://www.westword.com/news/auraria-campus-expansion-see-plans-for-newathletic-fields-and-more-5842589.

Pendergast, A. (2013c). Auraria as it used to be: Photos from a long-gone neighborhood. Retrieved from http://www.westword.com/news/auraria-as-it-used-to-be-photos-from-a-longgone-neighborhood-5828217.

Pendergast, A. (2013d). Auraria neighborhood “doomed," predicted 1975 campus impact study. Retrieved from http://www.westword.com/news/auraria-neighborhood-doomed-predicted-1975campus-impact-study-5850013.

Perry, D. C., Wiewel, W., \& Menendez, C. (2009, July). The university's role in urban development: From enclave to anchor institution. Lincoln Institute of Land Policy. Retrieved from https://www.lincolninst.edu/publications/articles/universitys-role-urban-development

Rapson, R. (2008). Positioning your university for investment: The university and urban renewal. Retrieved from https://kresge.org/library/positioning-your-university-investmentuniversity-and-urban-renewal.

Roberts, M. (2016). Sun Valley around Mile High Stadium. Retrieved from http://www.westword.com/news/inside-351-million-plus-plan-to-revitalize-sun-valley-aroundmile-high-stadium-8592047. 
Rutheiser, C. (2013). The anchor dashboard at the Department of Housing and Urban Development. Democracy Collaborative. Retrieved from http://democracycollaborative.org/ content/anchor-dashboard-department-housing-and-urban-development.

Sites, W. Chaskin, R. J., \& Parks, V. (2007). Reframing community practice for the $21^{\text {st }}$ Century: Multiple traditions, multiple challenges. Journal of Urban Affairs, 29(5), 519-541. https://doi.org/10.1111/j.1467-9906.2007.00363.x

Squires, G. D. (1989). Unequal partnerships: The political economy of urban redevelopment in postwar America. New Brunswick, NJ: Rutgers University Press.

The Democracy Collaborative of the University of Maryland. (2013). The anchor dashboard: Aligning institutional practice to meet low-income community needs. Retrieved from http://www.aecf.org/resources/the-anchor-dashboard-1/

Turner, M. A., Edelman, P., Poethig, E., Aron, L., Rogers, M., \& Lowenstein, C. (2014). Tackling persistent poverty in distressed urban neighborhoods: History, principles, and strategies for philanthropic investment. Retrieved from https://www.urban.org/sites/default/files/publication/22761/413179-tackling-persistent-povertyin-distressed-urban-neighborhoods.pdf

United States Environmental Protection Agency. (2016). Teaming up to make a visible difference in Sun Valley, Colorado. Retrieved from https://www.epa.gov/healthresearch/teaming-makevisible-difference-sun-valley-co.

Vaccarelli, J. (2016). Denver's Sun Valley neighborhood to receive \$30 million HUD grant. Retrieved from http://www.denverpost.com/2016/12/07/denver-sun-valley-neighborhood-hudgrant/.

Walker, L. A. \& East, J. F. (2014). The benefits of including engaged residents and professionals in low-income neighborhood redevelopment planning processes. Journal of Community Practice, 22(3), 342-364. https://doi.org/10.1080/10705422.2014.929063

Wilson, W. J. (1996). When work disappears: The world of the new urban poor. New York: Alfred A. Knopf Press.

Yates, G. \& Saasta, T. (2013). The why and how of engaging residents for change. National Civic Review, 102(3), 35-41. https://doi.org/10.1002/ncr.21138 


\section{Author Information}

* Laurie A. Walker was: (a) a community organizer in a neighborhood of this study that was funded by the Annie E. Casey Foundation; (b) a Housing and Urban Development - Office of University Partnerships Early Doctoral Student and Doctoral Dissertation Research Grant recipient from 2008-2012; and (c) a program evaluator of the Resident Advisory Council process evaluated. Laurie is the 2014 recipient of the Emerging Scholar Award from the Association for Community Organization and Social Administration and the 2017 recipient of the Ernest A. Lynton Award for the Scholarship of Engagement.

Laurie A. Walker, Ph.D.

School of Social Work

University of Montana

Jeannette Rankin Hall 004

32 Campus Dr.

Missoula, MT 59812-4680

Telephone: 406-243-2803

Email: Laurie.Walker@umontana.edu

Jean F. East is a community practice specialist and was an academic collaborator with the Annie E. Casey Foundation's Making Connections-Denver initiative during the 10 years of the program. She was the co-founder of Project WISE (Women's Initiative for Service and Empowerment), which was a community based organization partner in the Resident Advisory Council process. Jean was also Laurie's academic advisor during graduate school.

Jean F. East

Graduate School of Social Work

Craig Hall, Room 402

2148 S. High Street

Denver, CO 80208

Telephone: 303-871-2870

Email: Jean.East@du.edu

\section{Authors' Note}

Prepared under Grant Number H-21544SG from the Department of Housing and Urban Development, Office of University Partnerships. Points of views or opinions in this document are those of the authors and do not necessarily represent the official position or policies of the Department of Housing and Urban Development.

\footnotetext{
* Corresponding author
} 